\title{
The effect of aquatic and treadmill exercise in individuals with chronic stroke
}

\author{
Efeito do treinamento aeróbio em piscina e em esteira em hemiparéticos crônicos
}

El efecto del ejercicio en piscina y en cinta de correr en pacientes hemiparéticos crónicos

Patrícia Martins Franciulli', Aline Bigongiari², Juliana Valente Francica Grilletti ${ }^{3}$, Flávia de Andrade e Souza Mazuchi ${ }^{4}$, Alberto Carlos Amadio ${ }^{5}$, Luis Mochizuki ${ }^{6}$

\begin{abstract}
I We compared the effect of gait training on treadmill versus deep water on balance and gait in 12 ischemic stroke chronic survivors randomly sorted to the Pool or Treadmill Groups. Berg Scale (BBS) and timed up and go test (TUG) were applied before and after the interventions. Just one person applied all tests and she was blinded for the aims of the study. Surface EMG of the paretic and non-paretic (NP) side muscles were recorded during walking on a treadmill. Three 100-ms epochs were extracted from the EMG related to gait phases: weight acceptance; propulsion; and pre-strike. For each epoch, we calculated the RMS of the EMG signal. Participants did gait training for 9 weeks (3 times/week, 40 minutes/session). The Pool group did the deep-water walking with a swimming belt. The Treadmill group walked on the treadmill at the maximum speed they could stand. The Manova group compared the effect of training, group, side, muscles, and gait phase into the EMG. Anova was used to test the effect of training, group side, and gait phase into BBS, TUG and EMG variables. Pool and Treadmill had increased balance and agility. The highest EMG RMS occurred at the paretic side, for the Treadmill and after training. The $\mathrm{mm}$. tibialis anterior, gastrocnemius lateralis, vastus lateralis, and biceps femoris presented the highest RMS for the NP side; while for $\mathrm{mm}$. rectus femoris and semitendinosus, the paretic side presented the highest RMS. Thus, the both types of exercise lead to similar functional adaptations with different muscular activations during walking.
\end{abstract}

Keywords I Stroke; Gait; Electromyography; Aerobic Training.
RESUMO I Comparamos o efeito do treinamento de marcha em esteira versus piscina no equilíbrio e na marcha em 12 sobreviventes crônicos de AVC isquêmico separados aleatoriamente nos grupos piscina ou esteira. A escala de Berg (EEB) e timed up and go test (TUG) foram aplicados antes e após as intervenções. A EMG de superfície dos músculos do lado parético e não parético foi registrada na caminhada em esteira. Três janelas de 100 ms foram extraídas da EMG relacionada às fases da marcha: aceitação de peso; propulsão; e pré-contato do pé. Para cada fase, calculou-se o RMS do sinal EMG. Os participantes treinaram 9 semanas (3 vezes/semana, 40 minutos/sessão). O grupo piscina fez marcha na água com cinto de natação. O grupo esteira fez treinamento de marcha na na velocidade máxima confortável. A Manova comparou o efeito do treinamento, grupo, lado, músculos e fase da marcha na EMG. A Anova testou o efeito do treinamento, lado do grupo e fase da marcha nas variáveis BBS, TUG e EMG. Os grupos piscina e esteira aumentaram o equilíbrio e a agilidade. O maior EMG RMS ocorreu no lado parético, no grupo esteira e após o treinamento. Os músculos: tibial anterior, gastrocnêmio lateral, vasto lateral e bíceps femoral apresentaram o maior RMS para o lado não parético; enquanto para os músculos reto femoral e semitendíneo, o lado parético apresentou o maior RMS. Assim, os dois tipos de exercício levaram a adaptações funcionais semelhantes com diferentes ativações musculares durante a caminhada. Descritores | Acidente Vascular Cerebral; Marcha; Eletromiografia; Treinamento Aeróbio.

Study conducted at the Biomechanics Laboratory at the Escola de Educação Física e Esportes da Universidade de São Paulo (EEFE-USP) and the Biomechanics Laboratory at the Universidade São Judas Tadeu (USJT), São Paulo, SP, Brazil. Universidade São Judas Tadeu (USJT) - São Paulo (SP), Brazil. E-mail: pmfranciulli@gmail.com. Orcid: 0000-0002-0165-0932 ${ }^{2}$ Centro Universitário de Valença (Unifaa) - Valença (RJ), Brazil. E-mail: alinebigongiari@hotmail.com. Orcid: 0000-0002-7102-3897 ${ }^{3}$ Centro Universitário das Américas (FAM)- São Paulo (SP), Brazil. E-mail: juliana.grilletti@vemprafam.com.br. Orcid: 0000-0003-2669-5528 4University of Ottawa - Ottawa, Canada. E-mail: flavia.ft@hotmail.com. Orcid: 0000-0003-4781-4207

5Universidade de São Paulo (USP) - São Paulo (SP), Brazil. E-mail: acamadio@usp.br. Orcid: 0000-0002-2527-2163

GUniversidade de São Paulo (USP) - São Paulo (SP), Brazil. E-mail: mochi@usp.br. Orcid: 0000-0002-7550-2537 
RESUMEN I Se comparó el efecto del entrenamiento de la marcha en cinta de correr y en piscina en el equilibrio y la marcha de 12 sobrevivientes crónicos de accidente cerebrovascular isquémico, quienes fueron clasificados aleatoriamente en los grupos piscina o cinta de correr. Se aplicaron la Escala de Equilibrio de Berg (BBS) y la Timed up and go test (TUG) antes y después de las intervenciones. Solo una persona aplicó todas las pruebas con evaluación ciega para los objetivos del estudio. Se registró la EMG de superficie de los músculos laterales paréticos y no paréticos durante la caminata en la cinta. Se extrajeron tres momentos de 100 ms de la EMG relacionadas con las etapas de la marcha: aceptación de peso; propulsión; y precontacto del pie. Para cada momento, se calculó el RMS de la señal EMG. Los participantes realizaron entrenamientos de marcha durante 9 semanas (3 veces/semana, 40 minutos/sesión). El grupo piscina caminó con un cinturón de natación. El grupo cinta de correr caminó en la cinta a la velocidad máxima confortable. Utilizando la Manova se comparó el efecto del entrenamiento, el grupo, los músculos laterales y la fase de la marcha en la EMG. Con la ANOVA se probó el efecto del entrenamiento, el lado grupal y la fase de marcha en las variables BBS, TUG y EMG. El equilibrio y la agilidad aumentaron en ambos grupos. El EMG RMS más alto ocurrió en el lado parético del grupo cinta de correr y después del entrenamiento. Los músculos tibial anterior, gastrocnemio lateral, vasto lateral y bíceps femoral presentaron el RMS más alto en el lado no parético; mientras que en los músculos recto femoral y semitendinoso, el lado parético presentó el RMS más alto. Por lo tanto, los dos tipos de ejercicio conducen a adaptaciones funcionales similares con diferentes activaciones musculares durante la marcha. Palabras clave | Accidente Cerebrovascular; Marcha; Electromiografía; Tratamiento Aerobio.

\section{INTRODUCTION}

Stroke is the second most common cause of death worldwide and the primary cause of chronic disability in adults ${ }^{1,2}$. Without intense rehabilitation during the early days after the stroke, neural injuries gradually develop more pronounced motor impairments due to muscle weakness, spasticity and coordination loss ${ }^{3}$. Later, stroke survivors with chronic impairment become less independent to perform daily life activities, have less social interaction and are more concerned about their future ${ }^{4}$. Such dependent person with less social life can be considered as having lost motivation. This deprivation occurs because chronic stroke survivors have small resistance to fatigue $e^{4-6}$. They do not feel motivated to move continuously or for long periods since they get easily fatigued; as such, rehabilitation programs for such population should spare their activities between motor rehabilitation and increase in physical fitness in order to increase their resistance to fatigue.

In fact, about $80 \%$ of stroke survivors can walk without assistance; but their slow walk constrains their daily life activities $^{7,8}$. Walking speed is an important outcome for performance evaluation and for functional evaluation in stroke $^{9,10}$. The slow walking is due to the lower limb muscles spasticity ${ }^{11-14}$, muscle weakness, postural imbalance and fear of falling. Those clinical impairments also change the gait biomechanics ${ }^{15,16}$, inducing asymmetrical, stereotyped and low ranged compensatory movements ${ }^{17}$. At the early stage of the rehabilitation program, efforts should be addressed to improve body functions in enhance resistance to fatigue.
The aerobic training applied to stroke people enhances physical ability and improves life independence and quality, reducing morbidity and mortality ${ }^{18}$. Standard aerobic training is usually developed with walking and running. Treadmill protocols to stroke people can recover impaired gait, improve gait parameters and reduce walking asymmetries ${ }^{19}$. On the other hand, water walking enhances the afferent sensory inflow and improves peak aerobic capacity and walking endurance, being able to affect gait kinematics in patients with stroke ${ }^{18,20-22}$. It is not clear whether walking on water would provide the same or more benefits compared with the standard treadmill walking for chronic stroke people. In fact, little information is available to support a rehabilitation program for chronic stroke people with reduced mobility. The aim of this study was to compare the effect of aerobic training treadmill versus aerobic training in water for balance and gait in chronic stroke people. We expect that standard treadmill walking training and water walking training will not have similar biomechanical and functional results; therefore, both types of walking training will lead to similar functional results, but the electrical activity of lower limbs will show different behavior after training. Our first hypothesis is that treadmill gait training and deep-water gait training will lead to similar functional adaptations. Our second hypothesis is that treadmill gait training and deep-water gait training will induce different muscle adaptations that will provide different kinds of muscle activation during the walking test. We believe that training will improve participants' overall fitness, but training specificity will lead to differing muscle activation during the gait test. 


\section{METHODOLOGY}

This study was approved by the Ethics and Research Committee of Universidade São Judas Tadeu, under Opinion No. 093/2009, and all participants provided written informed consent.

\section{Participants}

Fifty adults were interested in joining this clinical trial. A total of 12 adults randomly sorted to the Pool Group or to the Treadmill Group participated in this study. Clinical characteristics of the participants are presented in Table 1. The randomization procedure was performed by a blind researcher and the sample was divided into two groups. The inclusion criteria were ischemic stroke in frontoparietal areas, more than one year after the last stroke, FAC score equal to or higher than 3, and not having participated in any physical exercises or rehabilitation programs. The exclusion criteria were heart disease, prior stroke, uncontrolled hypertension, not being able to walk in water or on the treadmill, and not being able to perform aerobic exercise.

Table 1. Demographic data on the participants

\begin{tabular}{|c|c|c|c|}
\hline Characteristics & $\begin{array}{l}\text { Treadmill }(n=6) \\
\text { Mean }(S D)\end{array}$ & $\begin{array}{l}\text { Pool }(n=6) \\
\text { Mean (SD) }\end{array}$ & P-value \\
\hline Age & $54.8(7.7)$ & $61.67(10.02)$ & 0.21 \\
\hline Sex & $5 F / 1 M$ & $5 F / 1 M$ & - \\
\hline Side stroke & $4 \mathrm{R} / 2 \mathrm{~L}$ & $4 \mathrm{~L} / 2 \mathrm{R}$ & - \\
\hline FAC score & $4(0.63)$ & $4.17(0.75)$ & 0.68 \\
\hline Time elapsed since stroke (months) & $56.67(32.93)$ & $67.67(51.05)$ & 0.66 \\
\hline Mini mental state examination & $24.17(4.17)$ & $24.50(4.32)$ & 0.89 \\
\hline Fulg-Meyer Assessment Scale & $144(38.02)$ & $140(10.25)$ & 0.80 \\
\hline
\end{tabular}

No statistical significance of differences between groups of muscles was determined by one-way repeated measures Anova followed by pos hoc Tukey test for intergroup comparisons.

\section{Procedures}

Berg balance scale (BBS) and timed up and go test (TUG) were applied before and after the interventions. The same person applied all tests and she was blinded with regard to the objective of the study. Myoelectrical activity of muscles (tibialis anterior, TA; gastrocnemius lateralis, $\mathrm{GL}$; rectus femoris, $\mathrm{RF}$; vastus lateralis, VL; biceps femoris, BF; and semitendinosus, ST) were recorded while walking on a treadmill $(0.28 \mathrm{~m} / \mathrm{s}$, for $60 \mathrm{~s})$. The right and left side muscles were recorded. Surface, disposable, bipolar electrodes were glued onto the skin above those muscles according to SENIAM recommendations ${ }^{23}$. Footswitches were glued to the left and right rear foot and forefoot, under the calcaneus bone and hallux. Electromyography (EMG) and footswitch signals were recorded (1kHz sampling frequency, 16-bit resolution) for 60s. Raw EMG signals were filtered (band-pass $4^{\text {th }}$ order Butterworth $20-500 \mathrm{~Hz}$ ), demeaned, full-wave rectified and smoothed (low-pass $4^{\text {th }}$ order Butterworth $20 \mathrm{~Hz}$ ). To remove EMG noise, the EMG histogram of each muscle was calculated, and signals bellow the $5 \%$ of maximal signal were subtracted. The EMG signals were cropped to ensemble one step and normalized with regard to time (step duration) and amplitude (95\% of maximal signal across all trials). Three $100-$ ms epochs were extracted from the EMG signal related to the gait phases: weight acceptance (from the foot strike up $100 \mathrm{~ms}$ later); propulsion (100ms before the foot off up to the foot off); and pre-strike (100ms before the foot strike up to the foot strike). For each epoch, the RMS (root mean square) of the EMG signal was calculated.

\section{Training protocol}

Submaximal aerobic test, the Naughton test, was applied to the participants to define their heart rate training. Naughton test is the best choice for subjects with serious physical limitations ${ }^{24}$. This protocol consists in a constant speed and slope increase every 2 minutes. Every step corresponds to 1 MET. The test was performed at submaximal intensity, that is, up to $85 \%$ of the maximum heart rate predicted for the age range or until it showed signs of excessive physical fatigue and changes in blood pressure for each phase that exceeds $20 \mathrm{mmHg}$ for systolic and $10 \mathrm{mmHg}$ for diastolic blood pressure. Perceived effort was measured using the Borg scale.

Participants continued to use their own medicine to reduce the risk for heart conditions and the occurrence of another stroke. 
The aerobic training lasted 9 weeks and was applied 3 times per week, for 40 minutes each session (5 minutes for warm-up [walking on the ground], 30 minutes for conditioning [treadmill or water], 5 minutes for cool-down [walking on the ground]). Heart rate and blood pressure were measured before and after each exercise session. The training had two phases: i) $1^{\text {st }}$ week, adaptation phase; and ii) $2^{\text {nd }}$ to last $9^{\text {th }}$ week, overload phase. During both phases, heart rate (HR) during warm-up and cool-down should not exceed $40 \%$ of its maximum; whereas during conditioning, for the $1^{\text {st }}$ week, HR should not exceed $50 \%$ of its maximum, and for the other 8 weeks, the maximum HR should be $60 \%$. The Pool group performed the aerobic training inside a pool. Water levels while walking should not exceed the xiphoid process, and participants wore a swimming belt to assist their buoyancy. Participants should do deep water walking with a swimming belt for 30 minutes. The water temperature was $33^{\circ} \mathrm{C}-35^{\circ} \mathrm{C}$. The Treadmill group performed the training at a treadmill, and subjects were attached to a safety harness system to avoid fallings. Participants should do stationary walking on the treadmill attached to the safety harness for 30 minutes at the maximum speed they could stand under the HR training limit.

\section{Statistical analysis}

Multiple analysis of variance (Manova) was applied to compare the effect of training (before and after), group (Pool and Treadmill), side (paretic and NP), muscles (TA, GL, RF, VL, BF, ST), and gait phase (terminal swing, initial contact and terminal stance) on electrical muscle activity (represented by the RMS of the EMG signal). Anova was applied to test the effect of training, group side, and gait phase on the BBS, TUG and EMG variables. The significance level was set at 5\%. All comparisons were performed with Statistica 9.0 (StatSoft, Inc).

\section{RESULTS}

\section{Functional evaluation}

The averages and standard deviations of BBS and TUG variables are presented in Table 2. These results were compared between groups and after training. There was no significant effect of group versus training interaction on the BBS and TUG variables. Training affected TUG $\left(\mathrm{F}_{1,286}=4.1\right.$ $\mathrm{p}<0.05)$ and $\mathrm{BBS}\left(\mathrm{F}_{1,260}=12.2 \mathrm{p}<0.05\right)$. The aerobic training increased balance and agility for Pool and Treadmill.

Table 2. Comparison of functional variables between two groups

\begin{tabular}{l|cc|cccc|c} 
Variables & \multicolumn{2}{c|}{ Pool } & \multicolumn{2}{c|}{ Treadmill } & Phase & Group & Phase $x$ Group \\
& BT & AT & BT & AT & p-value & $p$-value & $p$-value \\
Timed up and go test & $26.67(14.56)$ & $13.03(7.52)$ & $19(2.37)$ & $16.67(1.86)$ & $0.02^{*}$ & 0.50 & 0.11 \\
Berg balance scale & $41.67(6.38)$ & $49.17(4.31)$ & $42.33(4.55)$ & $48(4.31)$ & $0.00^{*}$ & 0.80 & 0.63
\end{tabular}

* Statistical significance; BT: before training; AT: after training; SD: standard deviation.

\section{EMG}

Average and standard deviation of the RMS EMG of paretic and non-paretic muscles during the gait phases are separated by groups and training, being presented in Table 3 . Multiple analysis of variance (Manova) was ran to check the main effect of the factors (training: before and after; group: Pool and Treadmill; side: paretic and NP; muscles: TA, GL, RF, VL, BF, ST; and gait phase: terminal swing, initial contact and terminal stance) into the RMS of each muscle. In general, the EMG RMS were affected by side $\left(\mathrm{F}_{1,38688}=919 \mathrm{p}<0.0001\right)$, group $\left(\mathrm{F}_{1,38688}=745 \mathrm{p}<0.0001\right)$, muscles $\left(\mathrm{F}_{11,38677}=1260 \mathrm{p}<0.0001\right)$, and training $\left(\mathrm{F}_{1,38688}=178 \mathrm{p}<0.0001\right)$.
The interaction side/group/training $\left(\mathrm{F}_{5,38688}=142 \mathrm{p}<0.0001\right)$ affected the RMS. The highest EMG RMS was observed at the paretic side, for the Treadmill and after the aerobic training $(\mathrm{p}<0.0001)$.

For every muscle, an Anova was run to check the effect of side, group and training. There was significant effect of side $\left(\mathrm{F}_{1,38397}>120 \mathrm{p}<0.001\right)$, group $\left(\mathrm{F}_{1,38397}>161 \mathrm{p}<0.001\right)$ and training $\left(\mathrm{F}_{1,38397}>245 \mathrm{p}<0.001\right)$. The EMG RMS was the highest for Treadmill and after training. The muscles TA, GL, VL and BF presented the highest RMS for the NP side; while for the muscles RF and ST, the paretic side presented the highest RMS and the muscles GL and $\mathrm{BF}$ presented similar RMS for NP and paretic sides. 
Table 3. RMS values of before and after treatment during gait for both groups

\begin{tabular}{|c|c|c|c|c|c|c|}
\hline Side & $\begin{array}{c}\text { Phases of } \\
\text { gait }\end{array}$ & Group & Phases of treatment & Stance & $\begin{array}{c}\text { RMS } \\
\text { Mean(SD) }\end{array}$ & $\mathbf{N}$ \\
\hline \multirow[t]{24}{*}{ Paretic } & \multirow{8}{*}{$\begin{array}{l}\text { Terminal } \\
\text { swing }\end{array}$} & \multirow[t]{4}{*}{ Treadmill } & \multirow[t]{2}{*}{ BT } & NP & $307.6(15.6)$ & 690 \\
\hline & & & & $P$ & $365.9(15.3)$ & 714 \\
\hline & & & \multirow[t]{2}{*}{ AT } & NP & $314.2(11.7)$ & 1236 \\
\hline & & & & $P$ & $431.6(16.3)$ & 630 \\
\hline & & \multirow[t]{4}{*}{ Pool } & \multirow[t]{2}{*}{ BT } & NP & $170.6(14.4)$ & 816 \\
\hline & & & & $P$ & $221.8(14.1)$ & 846 \\
\hline & & & \multirow[t]{2}{*}{ AT } & NP & $244.0(13.4)$ & 936 \\
\hline & & & & $P$ & 263.6(16.9) & 588 \\
\hline & \multirow[t]{8}{*}{ Initial contact } & \multirow[t]{4}{*}{ Treadmill } & \multirow[t]{2}{*}{ BT } & NP & $311.2(15.6)$ & 690 \\
\hline & & & & $P$ & $398.3(15.3)$ & 714 \\
\hline & & & \multirow[t]{2}{*}{ AT } & NP & $310.2(11.7)$ & 1236 \\
\hline & & & & $P$ & $432.0(16.3)$ & 630 \\
\hline & & \multirow[t]{4}{*}{ Pool } & \multirow[t]{2}{*}{ BT } & NP & $179.4(14.4)$ & 816 \\
\hline & & & & $P$ & $216.6(14.1)$ & 846 \\
\hline & & & \multirow[t]{2}{*}{ AT } & NP & $234.1(13.4)$ & 936 \\
\hline & & & & $P$ & 271.1(16.9) & 588 \\
\hline & \multirow{8}{*}{$\begin{array}{l}\text { Terminal } \\
\text { stance }\end{array}$} & \multirow[t]{4}{*}{ Treadmill } & \multirow[t]{2}{*}{ BT } & NP & $390.3(15.6)$ & 690 \\
\hline & & & & $P$ & $313.6(15.3)$ & 714 \\
\hline & & & \multirow[t]{2}{*}{ AT } & NP & $373.9(11.7)$ & 1236 \\
\hline & & & & $P$ & $395.2(16.3)$ & 630 \\
\hline & & \multirow[t]{4}{*}{ Pool } & \multirow[t]{2}{*}{ BT } & NP & $206.1(14.4)$ & 816 \\
\hline & & & & P & $194.7(14.1)$ & 846 \\
\hline & & & AT & NP & $246.5(13.4)$ & 936 \\
\hline & & & & $P$ & $281.0(16.9)$ & 588 \\
\hline Non-P & Terminal & Treadmill & BT & $N P$ & $143.3(15.6)$ & 690 \\
\hline & swing & & & $P$ & $110.5(15.3)$ & 714 \\
\hline & & & AT & NP & $284.0(11.7)$ & 1236 \\
\hline & & & & $P$ & $290.7(16.3)$ & 630 \\
\hline & & Pool & BT & NP & $133.4(14.4)$ & 816 \\
\hline & & & & $P$ & $93.9(14.1)$ & 846 \\
\hline & & & AT & NP & $111.7(13.4)$ & 936 \\
\hline & & & & $P$ & $101.0(16.9)$ & 588 \\
\hline & Initial contact & Treadmill & BT & NP & 165.1(15.6) & 690 \\
\hline & & & & $P$ & $115.2(11.7)$ & 714 \\
\hline & & & AT & NP & $311.6(16.3)$ & 1236 \\
\hline & & & & P & $310.1(16.3)$ & 630 \\
\hline & & Pool & BT & $N P$ & $152.0(14.4)$ & 816 \\
\hline & & & & $P$ & $116.2(14.1)$ & 846 \\
\hline & & & AT & NP & $107.7(13.4)$ & 936 \\
\hline & & & & $P$ & $121.3(16.9)$ & 588 \\
\hline & Terminal & Treadmill & BT & NP & $118.2(15.6)$ & 690 \\
\hline & stance & & & $P$ & $161.6(15.3)$ & 714 \\
\hline & & & AT & NP & $274.6(11.7)$ & 1236 \\
\hline & & & & P & 289.8(16.3) & 630 \\
\hline & & Pool & $\mathrm{BT}$ & NP & $105.7(14.4)$ & 816 \\
\hline & & & & P & $143.2(14.1)$ & 846 \\
\hline & & & AT & NP & 101.1(14.1) & 936 \\
\hline & & & & $P$ & $103.7(16.9)$ & 588 \\
\hline
\end{tabular}




\section{DISCUSSION}

Gait training is used in rehabilitation protocols for stroke survivors. We compared two protocols for the rehabilitation of chronic stroke survivors; while walking on the treadmill is the standard situation for this type of rehabilitation, walking in the water is an alternative for gait training. We set the same aerobic protocol for both types of gait training. We found that both types of training improve balance and agility. Muscle activation changes after that aerobic training. Therefore, gait becomes faster and more stable in chronic stroke people. Our results support the use of deep-water gait training to improve function in chronic stroke survivors.

Aerobic training benefits balance and mobility in chronic stroke survivors. Our results show that walking on treadmill and deep-water walking increased the BBS and TUG scores. These results support our first hypothesis that "treadmill gait training and deep-water gait training will lead to similar functional adaptations". In fact, other studies have shown that gait training in the rehabilitation pool or treadmill improves BBS after training ${ }^{25,26}$. Our first hypothesis was associated to the aerobic training effect and the importance of improving overall fitness state as a tool to improve function. Physical therapy sessions, muscle strength training, walking and balance training lead to better scores in TUG performed by chronic stroke people.

Flexibility increases with deep water gait training in chronic stroke survivors. Our results show that walking into the water has increased the passive ROM, whereas walking on the treadmill did the opposite: reduced the passive ROM. Propulsion in deep water walking is different because it comes from buoyancy and thrust. Then, lower limbs act during water gait like fins, which improves joint flexibility. When the environment was considered, the type of gait training (treadmill or deep water) induced an inverted effect.

Deep water walking improves balance in chronic stroke survivors. BBS score increased for the participants who trained deep water walking. Our results stress that training designed to enhance physical capacities such as aerobic resistance can induce other types of adaptation within the body. Nevertheless, sensory-motor impairments in both groups were similarly recovered after training.

Level of muscle activation changed after aerobic gait training for stroke, however, timing did not. The aerobic training was not able to affect the temporal pattern of muscle activation. Muscle activity during the three gait phases remained the same after training. When muscles change the timing and the level of activation along repetitions of the same task, different motor strategies might be the way to solve the same motor problem. The abundance of muscle pattern activations tells us that the motor system has several options to solve motor problems. After gait training, uncontrolled muscle reflex was depressed and substituted by voluntary muscle control. However, such effect was selective, and our results show that only biarticular spastic muscles increased their activity after training.

Different bellies of same muscle had different effects after gait training. The gait training changed the electrical activation of different bellies of the same muscle. This result strongly suggests that the impairment due to spasticity is counteracted by long-term gait training. It could also imply that motor strategies in chronic stroke people are not everlasting and can be modified by aerobic training. Moreover, the changes in hip muscle activation express the asymmetrical changes in muscle activation in stroke. The paretic hip muscles presented more activation compared to the NP side. Thus, spasticity is deprived in the paretic side. Otherwise, no change in hip muscle activation would be observed. To deal with the weakness and impairments in the paretic side, the contralateral hip muscle reduces their variability. This could be an adaptation to better absorb the impact during foot strike and better move the body during foot off.

Treadmill gait training improves muscle activation in stroke. The EMG of leg and thigh muscles showed higher RMS after treadmill gait training compared with deep water training. This result supports the second hypothesis: "Treadmill gait training and deep-water gait training will induce different muscle adaptations that will provide different muscle activations during the walking test". Off the water, the paretic muscles increased their activity. Such a result supports our second hypothesis. We proposed that the muscle activations would show different patterns between groups after training (training specificity effect). During the beginning of an aerobic exercise program, cardiovascular conditions improve faster than muscle strength. Therefore, the buoyancy effect might be a specific factor that underestimates gait training. Unfortunately, muscle strength does not increase enough under standard physical therapy sessions for stroke in order to perform other daily life activities ${ }^{27}$.

\section{CONCLUSION}

Our findings suggest that treadmill or aquatic training improves balance and gait in post-stroke individuals. Modifications in electromyographic activity occurred differently in both groups. We conclude that both types 
of aerobic exercise lead to similar functional adaptations with different muscular activation while walking.

\section{REFERENCES}

1. WHO [Internet]. Geneva: World Health Organization; 2013 [cited 2018 Apr 24]. Available from: https://bit.ly/2KgTxfd

2. Adrian C, Luminita V. Chronic kidney disease and stroke: more observations but no trials. Nephrol Dial Transplant. 2018;33(3):367-70. doi: 10.1093/ndt/gfx363

3. Bowden MG, Embry AE, Gregory CM. Physical therapy adjuvants to promote optimization of walking recovery after stroke. Stroke Res Treat. 2011(6):1-10. doi: 10.4061/2011/601416

4. Punt M, Bruijn SM, van Schooten KS, Pijnappels M, van de Port IG, Wittink H, et al. Characteristics of daily life gait in fall and non fall-prone stroke survivors and controls. J Neuroeng Rehabil. 2016;13(1):67. doi: 10.1186/s12984-016-0176-z

5. Acciarresi M, Bogousslavsky J, Paciaroni M. Post-stroke fatigue: epidemiology, clinical characteristics and treatment. Eur Neurol. 2014;72(5-6):255-61. doi: 10.1159/00036376

6. Billinger SA, Arena R, Bernhardt J, Eng JJ, Franklin BA, Johnson CM, et al. Physical activity and exercise recommendations for stroke survivors: a statement for healthcare professionals from the American Heart Association/ American Stroke Association. Stroke. 2014;45(8):2532-53. doi: 10.1161/STR.0000000000000022

7. Glader EV, Stegmayr B, Asplund K. Poststroke fatigue: a 2-year follow-up study of stroke patients in Sweden. Stroke. 2002;33(5):1327-33. doi: 10.1161/01.STR.0000014248. 28711.D6

8. Ada L, Dean CM, Hall JM, Bampton J, Crompton S. A treadmill and overground walking program improves walking in persons residing in the community after stroke: a placebo-controlled, randomized trial. Arch Phys Med Rehabil. 2003;84(10):1486-91. doi: 10.1016/S0003-9993(03)00349-6

9. Schmid AA, Rittman M. Consequences of poststroke falls: activity limitation, increased dependence, and the development of fear of falling. Am J Occup Ther. 2009;63(3):310-6. doi: 10.5014/ajot.63.3.310

10. Parvataneni K, Olney SJ, Brouwer B. Changes in muscle group work associated with changes in gait speed of persons with stroke. Clin Biomecha (Bristol, Avon). 2007;22(7):813-20. doi: 10.1016/j.clinbiomech.2007.03.006

11. Polese JC, Teixeira-Salmela LF, Nascimento LR, Faria CDM, Kirkwood RN, Laurentino GC et al. The effects of walking sticks on gait kinematics and kinetics with chronic stroke survivors. Clin Biomech (Bristol, Avon). 2012;27(2):131-7. doi: 10.1016/j.clinbiomech.2011.08.003

12. Verma R, Arya KN, Sharma P, Garg RK. Understanding gait control in post-stroke: implications for management. J Bodyw Mov Ther. 2012;16(1):14-21. doi: 10.1016/j.jbmt.2010.12.005

13. Hall AL, Peterson CL, Kautz SA, Neptune RR. Relationships between muscle contributions to walking subtasks and functional walking status in persons with post-stroke hemiparesis. Clin Biomech (Bristol, Avon). 2011;26(5):509-15. doi: 10.1016/j.clinbiomech.2010.12.010
14. Lamontagne A, Richards CL, Malouin F. Coactivation during gait as an adaptive behavior after stroke. J Electromyogr Kinesiol. 2000;10(6):407-15. doi: 10.1016/S1050-6411(00)00028-6

15. Jørgensen L, Engstad T, Jacobsen BK. Higher incidence of falls in long-term stroke survivors than in population controls: depressive symptoms predict falls after stroke. Stroke. 2002;33(2):542-7. doi: 10.1161/hs0202.102375

16. Pinter $M M$, Brainin $M$. Rehabilitation after stroke in older people. Maturitas. 2012;71(2):104-8. doi: 10.1016/j. maturitas.2011.11.011

17. Chen G, Patten C, Kothari DH, Zajac FE. Gait differences between individuals with post-stroke hemiparesis and non-disabled controls at matched speeds. Gait Posture. 2005;22(1):51-6. doi: 10.1016/j.gaitpost.2004.06.009

18. Mazuchi FAS, Bigongiari A, Francica JV, Franciulli PM, Mochizuki L, Hamill J, et al. Aerobic training in aquatic environment improves the position sense of stroke patients: a randomized clinical trial. Motriz: Rev Educ Fis. 2018;24(1):1-7. doi: 10.1590/s1980-6574201800010002

19. Gama GL, Celestino ML, Barela JA, Forrester L, Whitall J, Barela AM. Effects of gait training with body weight support on a treadmill versus overground in individuals with stroke. Arch Phys Med Rehabil. 2017;98(4):738-45. doi: 10.1016/j. apmr.2016.11.022

20. Han EY, Im SH. Effects of a 6-week aquatic treadmill exercise program on cardiorespiratory fitness and walking endurance in subacute stroke patients: a pilot trial. J Cardiopulm Rehabil Prev. 2018;38(5):314-9. doi: 10.1097/HCR.0000000000000243

21. Pereira JA, de Souza KK, Pereira SM, Ruschel C, Hubert M, Michaelsen SM. The kinematics of paretic lower limb in aquatic gait with equipment in people with post-stroke hemiparesis. Clin Biomech. 2019;70:16-22. doi: 10.1016/j.clinbiomech.2019.07.024

22. Katsura Y, Yoshikawa T, Ueda SY, Usui T, Sotobayashi D, Nakao $\mathrm{H}$, et al. Effects of aquatic exercise training using water-resistance equipment in elderly. Eur J Appl Physiol. 2010;108(5):957-64. doi: 10.1007/s00421-009-1306-0

23. Hermens HJ, Freriks B, Disselhorst-Klug C, Rau G. Development of recommendations for SEMG sensors and sensor placement procedures. J Electromyogr Kinesiol. 2000;10(5):361-74. doi: 10.1016/S1050-6411(00)00027-4

24. Meneghelo RS, Araújo CGS, Stein R, Mastrcolla LE, Albuquerque PF, Serra SM, et al. III Diretrizes da Sociedade Brasileira de Cardiologia sobre teste ergométrico. Arq Bras Cardiol. 2010;95(5):1-26. doi: 10.1590/S0066-782X2010000800001

25. Lee SH, Byun SD, Kim CH, Go JY, Nam HU, Huh JS, et al. Feasibility and effects of newly developed balance control trainer for mobility and balance in chronic stroke patients: a randomized controlled trial. Ann Rehabil Med. 2012;36:521-9. doi: 10.5535/arm.2012.36.4.521

26. Park JH, Chung YJ. Comparison of aquatic treadmill and antigravity treadmill gait training to improve balance and gait abilities in stroke patients. J Kor Phys Ther. 2018;30(2):67-72. doi: 10.18857/jkpt.2018.30.2.67

27. Fheodoroff K, Jacinto J, Geurts A, Molteni F, Franco JH, Santiago T, et al. How can we improve current practice in spastic paresis. Eur Neurol Rev. 2016;11:79-86. doi: 10.17925/ ENR.2016.11.02.79 